\title{
MEMINTA PERTANGGUNGJAWABAN PIDANA PERUSAHAAN INDUK ATAS PERBUATAN TINDAK PIDANA LINGKUNGAN HIDUP YANG DILAKUKAN OLEH ANAK PERUSAHAAN
}

\author{
Herlina Manullang \\ Dosen Fakultas Hukum Universitas HKBP Nommensen \\ Jl Sutomo No.4 A Medan \\ herlinamanullang63@gmail.com
}

\begin{abstract}
The role of corporations in the era of globalization has provided economic benefits for the world and also contributes to the country's income, especially providing for state income in the form of foreign exchange. But on the one hand the existence of a corporation also has a negative impact, such as the occurrence of environmental crimes. The occurrence of environmental crimes is due to the lack of corporate attention to the prevention and enforcement of environmental crimes. The existence of group companies today is still a long debate among experts, this difference is also towards the understanding of group companies. Differences of opinion occur due to the lack of juridical recognition of the status of a legal entity in a group company. Even Law No. 40 of 2017 concerning Limited Liability Companies does not regulate concretely with regard to the existence of group companies. The parent company as the controller of a subsidiary company may be held liable for criminal liability based on the doctrine of vicarious liability in the case of criminal liability of a subsidiary company in the event of an environmental crime. 116 of the Law on Environmental Protection and Management. Article 116 paragraph (2) of the Environmental Protection and Management Law, a parent company may be held liable for criminal actions on environmental actions committed by a subsidiary on the basis that the criminal act is not only committed by the subsidiary company, but the parent company, which controls the subsidiary company by operatingholding company, also participated in the occurrence of these environmental crimes.
\end{abstract}

\begin{abstract}
Abstrak, Peran korporasi di era globalisasi telah memberikan keuntungan ekonomi bagi dunia dan juga memberikan sumbangan pendapatan bagi negara, khususnya memberikan bagi pemasukan negara dalam bentuk devisa. Akan tetapi disatu sisi keberadaan korporasi juga memberikan dampak negatif, seperti terjadinya tindak pidana lingkungan hidup. Terjadinya tindak pidana lingkungan adalah disebabkan kurangnya perhatian korporasi terhadap pencegahan dan penegakan tindak pidana lingkungan.Keberadaan perusahaan group dewasa ini masih menjadi perdebatan yang panjang di kalangan para ahli, perbedaan ini sampai juga kearah pengertian perusahaan group.Perbedaan pendapat terjadi disebabkan belum adanya pengakuan yuridis terhadap status badan hukum pada perusahaan group.Bahkan UndangUndang No.40 Tahun 2017 tentang Perseroan Terbatas tidak mengatur secara konkret berkaitan dengan eksistensi perusahaan group.Perusahaan induk sebagai pengendali perusahaan anak dapat dimintakan pertanggungjawaban pidana berdasarkan doktrin tanggung jawab pengganti (vicarious liability) dalam hal pertanggunjawaban pidana perusahaan anak dalam hal terjadinya tindak pidana lingkungan hidup.Pasal 116 Undang-Undang Perlindungan dan Pengelolaan Lingkungan Hidup (UUPPLH). Pasal 116 ayat (2) UUPPLH, perusahaan induk dapat dimintakan pertanggungjawaban pidana atas tindakan lingkungan hidup yang dilakukan perusahaan anak dengan dasar bahwa tindak pidana tidak hanya dilakukan oleh
\end{abstract}


perusahaan anak, tetapi perusahaan induk, yang mengendalikan perusahaan anak secara operatingholding company, juga turut serta dalam terjadinya tindak pidana lingkungan tersebut.

Kała Kunci: Pertanggungjawaban Pidana, Penusahaan Induk, Tindak Pidana Lingkungan dan Anak perusahaan.

\section{Pendahuluan}

Globalisasi, perkembangan ilmu pengetahuan dan tehnologie yang dilakukan dewasa ini, tentu saja telah memberikan manfaat positif bagi kehidupan umat manusia dan juga harus diwaspadai efek sampingnya yang bersifat negatif, yaitu adanya "globalisasi kejahatan" dan meningkatnya kuantitas (jumlah) serta kualitas (modus operandi) tindak pidaana yang telah terjadi di berbagai negara. ${ }^{1}$

Globalisasi dan liberalisasi yang sedang berlangsung di era modern ini, telahmendorong lahirnya berbagai kejahatan-kejahatan baru di bidang ekonomi, bisnis, finansial, tehnologie dan lingkungan.Dampak yang timbul dari tindak pidana baru ini jauh lebih berbahaya dibandingkan dengan kejahatan konvensional bermotif ekonomi seperti pencurian, penggelapan, penipuan, dan perampokan. ${ }^{2}$ Dahulu ada semacam adegium yang menyatakan makin miskin suatu bangsa semakin tinggi semakin tinggi tingkat kejahatan yang terjadi.

Adagium di atas hanya berlaku bagi kejahatan konvensional seperti perampokan, pencurian, penipuan, penggelapan dan lain-lain. ${ }^{3}$ Soedjono Dirdjosisworo menyatakanbahwa :

"Kejahatan sekarang menunjukkan bahwa kemajuan ekonomi juga menimbulkan kejahatan bentuk baru yang tidak kurang bahaya dan besarnya korban yang diakibatkannya. Indonesia dewasa ini sudah dilanda kriminalitas kontemporer yang cukup mengancam lingkungan hidup, sumber energi dan pola-pola kejahatan di bidang ekonomi seperti kejahatan Bank, kejahatan komputer, kejahatan, penipuan terhadap konsumen berupa barang-barang produksi kualitas rendah yang dikemas indah dan dijajakan lewat advertensi secara besar-besaran dan berbagai pola kejahatan korporasi yang beroperasi lewat penetrasi dan penyamaran". ${ }^{4}$

Pada Laporan Kongres Perserikatan Bangsa-Bangsa (PBB) ke-5 dan ke-6 yang membahas mengenai The Prevention of Crime and The Treatment of Offenders terungkap

\footnotetext{
${ }^{1}$ Nyoman Serikat Putra Jaya, Globalisasi HAM dan Penegakan Hukum, Makalah disampaikan pada matrikulasi Mahasiswa Progran Magister Ilmu Hukum UNDIP tahun 2010, pada tanggal 18 Sepetember 2010, hlm. 1

${ }^{2}$ Rufinus Hotmaulana Hutauruk, Penanggulangan Kejahatan Korporasi Melalui Pendekatan Restoratif Justice Suatu Terobosan Hukum, (Jakarta: Sinar Grafika, 2013), hlm. 2

${ }^{3}$ Dwidja Priyatno, Pertanggungjawaban Pidana Korporasi, Makalah pada Simposiun Nasional Revitalisasi Hukum Pidana Adat dan Kriminologie Kontemporer Serta Pelatihan Hukum Pidana Dan Kriminologie Ke-V, Diselenggarakan Atas Kerjasama Bagian Hukum Pidana Fakultas Hukum Universitas Andalasa \& Masyarakat Hukum Pidana dan Kriminologie Indonesia (Mahupiki), Hotel Inna Muara, 2018, hlm. 1

${ }^{4}$ Soedjono Dirdjosisworo, Hukum Pidana Indonesia dan Gelagat Kriminalitas Masyarakat Pasca Industri, Pidato Pengukuhan Jabatan Guru Besar, (Bandung: Fakultas Hukum Universitas Panjajaran, 1991), hlm. 10 .
} 
bahwa "Crime As Business" atau "Kejahatan Dalam Lingkup Bisnis Yang sah" merupakan kejahatan atau tindak pidana dalam bidang bisnis atau industri yang secara umum dilakukan secara terorganisasi dan dilakukan oleh mereka yang mempunyai kedudukan yang terpandang atau berstatus sosial dalam masyarakat atau sering disebut dengan kejahatan white collar crime dan selalu dilakukan dalam skala bisnis yang besar (big business).

Keberadaan korporasi sebagai salah satu subyek hukum telah memberikan kontribusi yang besar pada pertumbuhan ekonomi dan pembangunan sebuah negara, tanpa terkecuali di Indonesia. Namun di sisi lain keberadaan korporasi telah menjadi alat dilakukannya beberapa tindak pidana yang memberikan dampak kerugian pada negara melalui tindak pidana korporasi (corporate crime).

Korporasi sebagai pelaku tindak pidana lebih dikenal dengan nama "Kejahatan Korporasi" atau "Tindak Pidana Korporasi", yaitu kejahatan atau tindak pidana yang dilakukan oleh korporasi. Korporasi sebagai pelaku tindak pidana telah mengalami beberapa perkembangan hukum, yaitu :

1. Korporasi tidak dapat melakukan tindak pidana dan tidak bisa dipertanggungjawabkan secara pidana. Pada tahap ini, tindak pidana yang dilakukan oleh korporasi dibatasi pada perorangan (manusia alamiah atau naturlijk person). Apabila suatu tindak pidana terjadi dilingkungan korporasi, maka tindak pidana tersebut dianggap dilakukan oleh pengurus korporasi tersebut. ${ }^{5}$

2. Korporasi dapat melakukan tindak pidana, namun tidak dapat dipertanggungjawabkan secara pidana. Pada tahap ini pertanggungjawaban pidana dapat dimintakan terhadap pengurus yang secara nyata memimpin korporasi tersebut. Oleh karena itu korporasi diakui dapat melakukan tindak pidana akan tetapi pihak yang mempertanggungjawabkan perbuatannya secara pidana adalah para anggotanya atau pengurusnya, sepanjang dinyatakan secara tegas dalam peraturan perundang atau pengurusnya, sepanjang dinyatakan secara tegas dalam peraturan perundang-undangan ataupun dalam aturan korporasi yang bersangkutan. Dengan demikian pada tahap ini, pertanggungjawaban pidana korporasi belum ada. $^{6}$

3. Korporasi dapat melakukan tindak pidana dan dapat dipertanggungjawabkan secara pidana. Pada tahap ini korporasi dinilai dapat melakukan tindak pidana dan mempertanggungjawabkan perbuatannya secara pidana. Alasan diaturnya korporasi sebagai pembuat tindak pidana sekaligus sebagai pihak yang harus mempertanggungjawabkan perbuatannya secara pidana karena dalam delik delik ekonomi atau tindak pidana ekonomi dan tidak pidana fiscal, keuntungan yang diperoleh korporasi atau kerugian yang diderita masyarakat dapat sedemikian besar, sehingga tidak akan mungkin seimbang apabila pidana hanya dijatuhkan kepada korporasinya saja, tidak atau belum ada jaminan bahwa korporasi tidak akan mengulangi tindak pidana atau kejahatan tersebut. Pemidanaan korporasi

\footnotetext{
${ }^{5}$ Muladi dan Dwidja Priyatna, Pertanggungjawaban Korporasi Dalam Hukum Pidana, (Bandung: STHB, 1991), hlm. 52

${ }^{6}$ Ibid
} 
dengan jenis dan beratnya yang sesuai dengan sifat korporasi itu, diharapkan dapat memaksa korporasi untuk mentaati peraturan yang bersangkutan. ${ }^{7}$

4. Pertanggungjawaban Pidana Korporasi dalam ketentuan umum Kitab UndangUndang Hukum Pidana (KUHPN), pada tahap ini, pengaturan tentang pertanggungjawaban tindak pidana korporasi tidak lagi tersebar di luar Kitab Undang-Undang Hukum Pidana (selanjutnya disebut KUHP). Pengaturan ini masih bersifat ius constituendum, yaitu mengatur sistem pertanggungjawaban pidana korporasi secara umum dalam buku I KUHP Nasional, sehingga akan berlaku untuk semua jenis tindak pidana. ${ }^{8}$

KUHP sekarang ini belum mengakui korporasi sebagai subyek hukum pidana.KUHP hanya mengenal orang (person) sebagai pelaku tindak pidana.Apabila tindak pidana dilakukan oleh orang-orang yang ada dalam korporasi, maka yang bertanggungjawab adalah pengurus yang secara riil melakukan tindak pidana, maka yang bertanggungjawab adalah pengurus yang secara riil melakukan tindak pidana.Ketentuan tersebut sebagaimana diatur dalam Pasal 59 KUHP.

Pada perkembangan selanjutanyaMahkamah Agung (MA) telah menerbitkan Peraturan Mahkamah Agung No.13 Tahun 2016 Tentang Tata Cara Penanganan Perkara Tindak Pidana Oleh Korporasi (selanjutnya disebut Perma No 13 Tahun 2016) mengakui korporasi sebagai pelaku tindak pidana dan bisa dipertanggungjawabkan.

Pertanggungjawaban pidana merupakan suatu proses dilanjutkannyacelaan (verwijtbaarheid) yang obyektif terhadap perbuatan yang dinyatakan sebagai tindak pidana oleh hukum pidana dan si pelaku merupakan subyek hukum yang dianggap memenuhi persyaratan untuk dijatuhi pidana. ${ }^{9}$ Menurut hukum pidana, syarat utama atau prinsip utama adanya pertanggungjawaban pidana adalah ada kesalahan dan pembuat harus mampu bertanggungjawab. Defenisi kesalahan secara jelas diberikan oleh Remmelink sebagai pencelaan yang ditujukan kepada masyarakat yang menerapkan standard etis yang berlaku pada waktu tertentu terhadap manusia yang melakukan perilaku menyimpang yang sebenarnya dapat dihindari. ${ }^{10}$ Sebagaimana adagiumfacinus quos inquinataequat yang menyatakan bahwa kesalahan selalu melekat pada orang yang berbuat salah.Berdasarkan defenisi tersebut kesalahan bertalian dua hal, yaitu sifat dapat dicelanya (verwijtbaarheid) perbuatan dan sifatnya dapat dihindarkan (vermijdbaarheid) perbuatan yang melawan hukum. ${ }^{11}$

\footnotetext{
${ }^{7}$ Dwidja Priyatno, Kebijakan Legislasi Tentang Sistem Pertanggungjawaban Pidana Korporasi diIndonesia, Bandung: CV Utomo, 2003), hlm. 27 .

${ }^{8}$ Kristian, Kejahatan Korporasi di Era Modern dan Sistem Pertanggungjawaban Pidana Korporasi, (Bandung: Refika Aditama,, 2016), hlm. 174

${ }^{9}$ Herlina Manullang, Pertanggungjawaban Pidana Badan Usaha Commanditaire Venootschaap Dalam Tindak Pidana Lingkungan Hidup, Disertasi, (Medan: USU, 2016), hal 43

${ }^{10}$ Jan Remmelink, Hukum Pidana;Komentar Atas Pasal-Pasal Terpenting Dalam Kitab Undang-Undang Hukum Pidana Belanda dan Padanaannya Dalam Kitab Undang-Undang Hukum Pidana Indonesia, (Jakarta: Gramedia Pustaka Utama, 2003), hlm. 390.

${ }^{11}$ Eddy.OS.Hiariey, Prinsip-Prinsip Hukum Pidana, (Yogjakarta: Cahaya Atma Pustaka. 2014), hlm. 123.
} 
Terjadinya tindak pidana lingkungan hidup berupa pencemaran dan/atau perusakan lingkungan, kebanyakan dilakukan dalam konteks menjalankan usaha ekonomi, dan juga merupakan sikap penguasa dan pengusaha yang tidak menjalankan atau melalaikan kewajiban-kewajiban dalam pengelolaan lingkungan hidup. ${ }^{12}$ Pencemaran dan/atau perusakan lingkungan terus meningkat sejalan dengan meningkatnya kegiatan industri atau sejenisnya, tentunya lingkungan hidup perlu mendapatkan perlindungan hukum. ${ }^{13}$

Pasal 116 Undang-Undang Perlindungan dan Pengelolaan Lingkungan Hidup (UUPPLH), menjadikan konsep pertanggungjawaban pidana korporasi dan pengurus korporasi (direktur, para manager yang bertanggungjawab dalam pengelolaan lingkungan hidup perusahaan, bahkan dapat dimintakan kepada para pemegang saham maupun para komisaris) secara bersama-sama, dalam hal kegiatan dan/atau usaha korporasi tersebut menyebabkan terjadinya pencemaran dan/atau perusakan lingkungan hidup. Selanjutnya Pasal 116 UUPPLH menyebutkan antara lain:

(1) Apabila ketentuan pidana lingkungan hidup dilakukan oleh, untuk, atau atas nama badan usaha, tuntutan pidana dan sanksi pidana dijatuhkan kepada ;

a. badan usaha; dan/atau

b. orang yang memberi perintah untuk melakukan tindak pidana tersebut atau orang yang bertindak sebagai pemimpin kegiatan dalam tindak pidana tersebut.

(2) Apabila tindak pidana lingkungan hidup sebagaimana dimaksud pada ayat (1) dilakukan oleh orang, yang berdasarkan hubungan kerja atau berdasarkan hubungan lain bertindak dalam lingkup kerja badan usaha, sanksi pidana dijatuhkan terhadap pemberi perintah atau pemimpin dalam tindak pidana tersebut tanpa memperhatikan tindak pidana tersebut dilakukan secara sendiri atau bersama sama.

Ketentuan Pasal 116 UUPPLH mengatur tentang pertanggungjawaban pidana dalam hal tindak pidana dilakukan oleh, untuk dan atas nama badan usaha. Sehubungan dengan pertanggungjawaban pidana harus jelas terlebih dahulu mengenai siapa yang dapat dipertanggungjawabkan.Artinya, harus terlebih dahulu dipastikan siapa yang dinyatakan sebagai pembuat tindak pidana tersebut.Mengenai siapa yang dinyatakan sebagai pembuat tindak pidana (subyek tindak pidana) pada umumnya sudah dirumuskan oleh pembuat undang-undang. ${ }^{14}$

Isu hukum yang muncul dewasa ini tentang korporasi adalah terjadinya perubahan yang sangat cepat dan fundamental berkaitan dengan bentuk serta tanggung jawab sebuah korporasi. Dahulu dikenal adanya korporasi tunggal yang hanya bertanggungjawab terhadap seluruh kegiatan yang dilakukan secara pribadi, namun disebabkan semakin

\footnotetext{
${ }^{12}$ Boed Wahono, Pertanggungjawaban Pidana Korporasi, (Jakarta: Kencana Prenada Media Group, 2010), hlm. 32-33.

${ }^{13}$ Alvi Syahrin, Ketentuan Pidana Dalam UU No.32 Tahun 2009 Tentang Perlindungan dan Pengelolaan Lingkungan Hidup, (Jakarta: Sofmedia, 2011), hlm. 57

${ }^{14}$ Mulyadi dan Dwidja Priyatno, Pertanggungjawaban Pidana Korporasi Dalam Hukum Pidana, (Bandung: Sekolah Tinggi Hukum, 1991), hlm. 66-67.
} 
kompleksnya dunia usaha serta persaingan dan globalisasi yang semakin tajam, maka muncullah konsep perusahaan group yang menaungi beberapa perusahaan anak

Pencemaran dan/atau kerusakan lingkungan hidup yang dilakukan oleh satu beberapa perusahaan anak dapat saja terjadi dalam suatu struktur perusahaan group.Ada kalanya tindakan pencemaran dan/atau perusakan lingkungan hidup dilakukan oleh perusahaan anak tersebut yang merupakan tindakan yang harus dilakukan oleh perusahaan induk demi memperoleh keuntungan tertentu. Ketentuan perundang-undangan seperti UU No.40 Tahun 2007 tentang Perseroan Terbatas (selanjutnya disebut UU PT) atau perundang-undangan lainnya, telah dikontruksikan oleh keterkaitan antara induk perusahaan dan anak perusahaan yang berbadan hukum mandiri. Induk perusahaan bertindak sebagai pimpinan sentral yang mengendalikan dan mengkoordinasikan anakanak perusahaan group sebagai satu kesatuan ekonomi. ${ }^{15}$ Berdasarkan pengertian di atas maka muncul rantai komando dalam pengelolaan perusahaan group yang nantinya akan muncul tanggung jawab yang saling terkait antara anak perusahaan dengan induk perusahaan dimana induk perusahaan memegang pimpinan sentral dalam pengendalian serta penentu kebijakan pada anak perusahaan yang dinaunginya. Pelaksanaan pengaruh dalam perusahaan group dapat bersifat mengurangi hak atau mendominasi hak perusahaan lain, atas kewenangan induk perusahaan untuk mengendalikan anak perusahaan, induk perusahaan dianggap menjalankan fungsi sebagai holding company ${ }^{16} \mathrm{Hal}$ inilah yang mendasari bahwa perusahaan induk dapat dimintakan pertanggungjawaban pidana atas tindak pidana lingkungan hidup yang dilakukan oleh perusahaan anak.

Berdasarkan uraian latar belakang di atas maka dalam penelitian ini yang menjadi permasalahan yaitu:

1. Bagaimanakah hubungan hukum antara perusahaan anak dengan perusahaan induk di dalam sebuah perusahaan group ?.

2. Bagaimanakah konsep pertanggungjawaban pidana perusahaan indukatas perbuatan tindak pidana lingkungan hidup yang dilakukan oleh anak perusahaan?

\section{Metode Penelitian}

Penelitian ini merupakan penelitian deskriptif, berupaya menjelaskan permasalahan pertanggungjawaban pidana perusahaan induk dalam tindak pidana lingkungan hidup di Indonesia. Menggunakan pendekatan yuridis normatif lebih khususnya pendekatan Undang-Undang dan pendekatan hermeunetika hukum dengan melakukan penafsiran terhadap ketentuan hukum yang berkaitan dengan pertanggungjawaban pidana perusahaan induk dalam tindak pidana lingkungan hidup di Indonesia. ${ }^{17}$

\footnotetext{
${ }^{15}$ Sulistiowati, Aspek Hukum dan Realitas Bisnis Perusahaan Group Di Indonesia, Cet Pertama, (Jakarta: Erlangga,, 2010), hlm. 21.

${ }^{16}$ Ibid

${ }^{17}$ Sukmareni, Pertanggungjawaban Pidana Korporasi Terhadap Tindak Korupsi Dalam SistemPeradilan Indonesia, dalam Revitalisasi Hukum Pidana Adat dan Kriminologie Kontemporer, Proceeding Call for Papers pada Simposium dan Pelatihan Hukum Pidana Ke V
} 
Bahan Hukum yang digunakan bahan hukum baik primer, sekunder maupun bahan hukum tertier melalui studi kepustakaan, yang dilakukan analisanya dengan analisa kualitatif dengan mengembalikan permasalahan yang ada kepada perundang-undangan yang berlaku di Indonesia.

\section{Pembahasan}

\section{Hubungan Hukum Antara Perusahan Induk Dengan Perusahaan Anak Dalam Suatu Perusahaan Group.}

Keberadaan perusahaan group dewasa ini masih menjadi perdebatan yang panjang di kalangan para ahli, perbedaan ini sampai juga kearah pengertian perusahaan group. Perusahaan group merupakan gabungan atau susunan perusahaan-perusahaan yang secara yuridis mandiri, yang satu sama lain saling terkait begitu erat sehingga membentuk satu kesatuan eknonomi yang tunduk kepada suatu pimpinan perusahaan induk sebagai pimpinan sentral. ${ }^{18}$ Perusahaan group tumbuh akibat dari perkembangan zaman. Disatu sisi pembentukan perusahaan group diIndonesia diharapkan dapat meningkatan pendapatan dan perekonomian negara, serta terkait dengan pengelolaan melalui perusahaan group dapat memberikan manfaat ekonomi, ${ }^{19}$ namun tidak berarti secara hukum memberi peluang munculnya moral hazard atas sikap oportunitis induk perusahaan yang menyalahgunakan konstruksi perusahaan group. Induk perusahaan memperoleh dominasi terhadap pengurusan anak perusahaan dan terhindar dari tanggungjawab hukum (baik terhadap pihak ketiga) sebagai akibat hukum dari perbuatan anak perusahaan yang menjalankan instruksi perusahaan. ${ }^{20}$

Di dalam penjelasan Pasal 29 Undang-Undang No. 1 Tahun 1995 (UUPT sebelum Undang- Undang No. 40 Tahun 2207) pengertian perusahaan anak atau "anak perusahaan" adalah perseroan yang memiliki hubungan khusus dengan perseroan lainnya yang terjadi karena: ${ }^{21}$

a. Lebih dari 50\% (lima puluh persen) sahamnya dimiliki oleh perusahaan induknya;

b. Lebih dari $50 \%$ (lima puluh persen) suara dalam RUPS dikuasai oleh perusahaan induknya; dan atau

c. Kontrol atas jalannya perseroan, pengangkatan, dan pemberhentian direksi dan komisaris sangat dipengaruhi oleh perusahaan induknya.

Perusahaan group dikonstruksikan oleh keterkaitan antar induk perusahaan dan anak perusahaan yang berbadan hukum mandiri.Induk perusahaan bertindak sebagai

Diselenggarakan atas kerjasama Fakultas Hukum Universitas Andalas Padang dengan MAHUPIKI, (Jokjakarta: Genta Publishing, 2018), hlm. 585

${ }^{18}$ Emmy Pangaribuan , Perusahaan Kelompok (Group Company/Concern), Seri Hukum Dagang, (Yokjakarta: Fakultas Hukum Universitas Gajah Mada, 1994), hlm. 8.

${ }^{19}$ bid

${ }^{20}$ Alvi Syahrin, Pertanggungjawaban Pidana Korporasi Dalam Ketentuan Pidana UndangUndang No.32 Tahun 2009 tentang Perlindungan dan Pengelolaan Lingkungan Hidup, Makalah, Disampaikan pada kegiatan "Simposiun Nasional, Pelatihan Hukum Pidana dan Kriminologie" Mahupiki, Padang, 3 April 2018, hlm.13

${ }^{21}$ Lihat Memori Penjelasan Pasal 29 Undang-Undang Nomor 1 Tahun 1995 tentang Perseroan Terbatas. 
pimpinan sentral yang mengendalikan dan mengoordinasikan anak-anak perusahaan dalam satu kesatuan manajemen bagi tercapainya tujuan kolektif perusahaan group sebagai satu kesatuan ekonomi ${ }^{22}$ Perusahaan group tidak merujuk kepada suatu badan hukum tertentu, tetapi satu kesatuan ekonomi dari perusahaan-perusahaan yang bergabung di dalamnya terdapat induk dan anak perusahaan (bahkan sampai cucu perusahaan). Belum adanya pengaturan secara khusus tentang perusahaan grup di Indonesia, maka induk dan anak perusahaan dalam suatu perusahaan grup diperlakukan sebagaimana halnya status badan hukum masing-masing induk dan anak perusahaan. Tergabungnya induk dan anak perusahaan dalam konstruksi perusahaan group tidak menghapus status badan hukum induk dan anak perusahaan. ${ }^{23}$

Pengakuan yurudis terhadap induk dan anak perusahaan sebagai subyek hukum mandiri menyebabkan induk dan anak perusahaan berhak melakukan perbuatan hukum sendiri, namun faktanya pengendalian induk perusahaan kepada anak perusahaan dari realitas bisnis perusahaan grup yang dikelola sebagai kesatuan ekonomi.Pengendalian induk perusahaan terhadap anak perusahaan dalam konstruksi perusahaan grup menimbulkan dualitas pada anak perusahaan, yakni sebagai badan hukum yang mandiri dan badan usaha yang tunduk di bawah kendali induk perusahaan. Fakta pengendalian induk terhadap anak perusahaan dari realitas bisnis perusahaan group tidaklah menghapuskan pengakuan secara yuridis terhadap suatu badan hukum anak perusahaan sebagai subyekhukum mandiri, sebaliknya pengurusan anak perusahaan tidak dapat dilepas dari adanya fakta pengendalian induk terhadap anak perusahaan dari realitas bisnis perusahaan grup yang dijalankan dalam satu kesatuan ekonomi. Pengendalian induk terhadap anak perusahaan yang berupa kebijakan atau instruksi mempengaruhi drajat kemandirian anak perusahaan untuk tidak menjalankan kebijakan dan atau instruksi dari induk perusahaan. ${ }^{24}$

\section{Pertanggungjawaban Pidana Perusahaan Induk Atas Perbuatan Tindak Pidana Lingkungan Hidup Yang Dilakukan oleh Anak Perusahaan}

Perusahaan induk sebagai pengendali perusahaan anak dapat dimintakan pertanggungjawaban pidana berdasarkan doktrin tanggung jawab pengganti (vicarious liability) dalam hal pertanggungjawaban pidana perusahaan anak dalam hal terjadinya tindak pidana lingkungan hidup.Doktrin vicarious liability mengajarkan bahwa pertanggungjawaban hukum terhadap seseorang, dalam hal perusahaan induk dilakukan oleh orang lain, yaitu perusahaan anak.

Perusahaan induk yang dapat dimintakan pertanggungjawaban pidana atas tindak pidana lingkungan yang dilakukan oleh perusahaan anaknya adalah perusahaan induk yang secara langsung ikut mengendalikan perusahaan anaknya tersebut dan juga ikut beroperasisecara aktif dalam menjalankan kegiatan usaha perusahaan anak. Model pengendalian yang demikian disebut dengan operating holding company. Pada operating

\footnotetext{
${ }^{22}$ Susilawati $O p$ cit, hlm.17.

${ }^{23}$ Alvi SyahrinOp cit, hlm.13

${ }^{24}$ Ibid
} 
holding company perusahaan induk menjalankan kegiatan usaha atau mengendalikan perusahaan anaknya, ${ }^{25}$ dan dalam mencapai tujuannya perusahaan induk dapat menentukan kebijakan kebijakan yang kemudian akan dilaksanakan oleh perusahaan anaknya.

Pasal 116 UU No 32 Tahun 2009 UUPPLH telah mengatur tentang Pertanggungjawaban pidana dalam hal tindak pidana dilakukan oleh, untuk dan atas nama badan usaha. Berkaitan dengan pertanggungjawaban pidana tersebut harus jelas terlebih dahulu mengenai siapa yang dapat dimintakan pertanggungjawaban pidana.Maksudnya, haruslah terlebih dahulu dipastikan siapa yang dinyatakan sebagai pembuat tindak pidana.Artinya, haruslah lebih dahulu ditentukan siapa yang dinyatakan sebagai pembuat tindak pidana tersebut.mengenai siapa yang dinyatakan sebagai pembuat tindak pidana (subyek tindak pidana) secara umum telah dirumuskan oleh pembuat undang-undang.

Pasal 116 UUPPLH dan penjelasannya, tindak pidana lingkungan hidup dilakukan oleh, untuk dan atas nama badan usaha, sehingga perlu dilakukan penafsiran. Penafsiran terhadap tindak pidana lingkungan dilakukan oleh badan usaha berarti badan usaha sebagai pelaku, badan usaha dalam hal ini sebagai pelaku pasif, sedangkan pelaku aktifnya seperti : para pengurus badan usaha atau para manajer badan usaha melakukan perbuatan tersebut oleh karena jabatannya. Penafsiran terhadap tindak pidana lingkungan dilakukan untuk badan usaha berarti badan usaha dinyatakan sebagai pelaku oleh karena badan usaha menerima tindak pidana tersebut sebagai suatu perbuatan sesuai dengan tujuan, maksud atau badan usaha menerima perbuatan tersebut yang dilakukan oleh pengurus badan usaha atau para manajer badan usaha. Sedangkan panfsiran tindak pidana lingkungan dilakukan atas nama badan usaha berarti badan usaha sebagai pelaku oleh karena perbuatan itu dilakukan oleh para pengurus badan usaha atau para menejernya badan usaha. Oleh karena itu, pelaku tindak pidana lingkungan sebagaimana dimaksud Pasal 116 UUPPLH adalah :

a. dilakukan oleh badan usaha;

b. dilakukan untuk badan usaha;

c. dilakukan atas nama badan usaha;

d. dilakukan oleh badan usaha yang dilakukan oleh orang yang berdasarkanhubungan kerja yang bertindak dalam lingkup badan usaha :

e. dilakukan oleh badan usaha yang dilakukan oleh orang berdasarkan hubunganlain yang bertindak dalam lingkup kerja badan usaha;

f. dilakukan untuk badan usaha yang dilakukan oleh orang yang berdasarkanhubungan kerja yang bertindak dalam dalam lingkup kerja badan usaha ;

g. dilakukan untukbadan usaha yang dilakukan oleh orang yang berdasarkan hubungan lain yang bertindak dalam lingkup kerja badan usaha :

h. dilakukan atas nama badanusaha yang dilakukan oleh orang yangberdasarkan hubungan kerja yang bertindak dalam lingkup kerja badan usaha ;

\footnotetext{
${ }^{25}$ Susilawati $O p$ cit, hlm.25.
} 
i. dilakukanatas nama badan usaha yang dilakukan oleh orang yangberdasarkan hubungan lain yang bertindak dalam lingkup kerja badan usaha.

Korporasi sebagai pelaku tindak pidana lingkungan meskipun perlu diterapkan haruslah memperhatikan kasus per kasus (kasuistis) sesuai dengan sifat tindak pidana tertentu yang bisa sebagai berupa pidana fungsional yang lebih bersifat administratif dan tindak pidana non-fungsional yang lebih bersifat fisik, perlu juga dipedomani atau memperhatikan bahwa; ${ }^{26}$

1. Perbuatan dari perorangan dapat dibebankan kepada badan usaha, apabila perbuatan-perbuatan tersebut tercermin dalam lalu lintas sosial sebagai perbuatanperbuatan badan usaha;

2. Apabila sifat dan tujuan pengaturan telah menunjukkan indikasi untuk pembuat pidana, untuk pembuktian akhir pembuat pidana, di samping apakah perbuatan tersebut sesuai dengan tujuan statuta (anggaran dasar dan anggaran rumah tangga) dari korporasi dan atau sesuai dengan kebijaksanaan korporasi, dalam arti tindakan atau perbuatan tersebut sesuai dengan ruang lingkup pekerjaan dari korporasi ;

3. Perbuatan yang terlarang yang untuk mempertanggungjawabkan dibebankan kepada korporasi dilakukan dalam rangka pelaksanaan tugas dan atau pencapaian tujuan-tujuan badan usaha tersebut ;

4. Perbuatan pengurus korporasi dianggap sebagai perbuatan korporasi itu sendiri dalam hal pengurus korporasi mempunyai kewenangan atau kekuasaan dalam hal (untuk) menentukan apakah perbuatan itu dilakukan atau tidak, dan perbuatan itu harus merupakan bagian dari perbuatan-perbuatan yang menurut kenyataan diterima atau lazimnya diterima oleh korporasi. Syarat kekuasaan (machtsvereiste) mencakup; wewenang mengatur/menguasai dan memerintah pihak yang dalam kemyataan melakukan tindak pidana lingkunga; mampu melaksanakan wewenangnya dan pada dasarnya mampu mengambil keputusan-keputusan tentang hal bersangkutan; dan mampu mengupayakan kebijakan atau tindakan pengaman dalam rangka mencegah dilakukannya tindak pidana lingkungan..selanjutnya, syarat penerimaan atau akseptasi (aanvaardingsvereiste) terjadi apabila ada kaitan erat antara proses pengambilan atau pembentukan keputusan di korporasi dengan tindak pidana lingkungan yang dilakukan termasuk juga adanya kemampuan pengawasan secara cukup. Dengan demikian, perbuatan karyawan korporasi hanya akan dipertimbangkan sebagai perbuatan pimpinan, apabila : a perbuatannya dalam kerangka kewenangannya untuk menentukan pegawai tersebut untuk berbuat; dan b. perbuatan karyawan masuk dalam kategori perbuatan yang accepted oleh korporasi dalam kerangka bisnis yang normal.

5. Kesengajaan korporasi terjadi dalam hal kesengajaan itu pada kenyataannya tercakup dalam politik dan tujuan korporasi, atau berada dalam kegiatan yang nyata dari korporasi tersebut. Kesengajaan korporasi juga bisa timbul dalam hal kesengajaan dari perorangan (natuurlijk person) yang berbuat atas nama korporasi.

\footnotetext{
${ }^{26}$ Alvi Syahrin, Opcit, hlm. 14
} 
6. Kesengajaan suatu organ dari korporasi dapat dipertanggungjawabkan secara hukum. Dalam hal tertentu, kesengajaan dari seorang bawahan bahkan dari orang/pihak ketiga, dapat mengakibatkan kesengajaan korporasi. Artinya, tidak hanya tindakan sengaja fungsionaris pimpinan korporasi yang dapat diatribusikan pada korporasi, tetapi juga termasuk tindakan pegawai/ karyawan rendahan ;

7. Pertanggungjawaban pidana juga bergantung kepada organisasi internal dalam korporasi dan cara bagaimana pertanggungjawaban dibagi, demikian juga halnya dengan kealpaan;

8. Pengetahuan bersama dari sebagian besar anggota direksi atau pengurus korporasi dapat dianggap sebagau kesengajaan korporasi, bahkan sampai kepada kesengajaan berinsyaf (sadar akan) kemungkinan atau opzet mogelijkheidsbewusstjzin atau dolus evantualis .

Isu hukum yang menjadi persoalan dari perusahaan group dalam hal terjadinya tindak pidana tindak pidana lingkungan yang dilakukan oleh anak perusahaan, akan tetapi tindak pidana yang dilakukan oleh anak perusahaan tersebut akibat dari adanya kebijakan dan atau instruksi dari induk perusahaan sehingga anak perusahaan menjadi tidak dapat melakasanakan kewajiban untuk melakukan perlindungan dan pengelolaan lingkungan hidup. Dalam hal ini, apakah induk perusahaan dapat dinyatakan sebagai "orang yang memberi perintah untuk melakukan tindak pidana" atau orang yang bertindak sebagai pemimpinan kegiatan tindak pidana", sebagaimana yang disebutkan di dalam Pasal 116 (2) UUPPLH.

Untuk dapat dimintakan pertanggungjawaban pidana kepada perusahaan group atas perbuatan tindak pidana lingkungan yang dilakukan oleh anak perusahaan, perlu dibuktikan dengan adanya fakta pengendalian perusahaan induk terhadap anak perusahaan yang menyebabkan anak perusahaan tidak dapat melaksanakan kewajiban untuk melakukan perlindungan dan pengeloan lingkungan hidup, sebagaimana yang diatur dalam pasal 68 UUPPLH yaitu ;

1. Memberikan informasi yang terkait dengan perlindungan dan pengelolaan lingkungan hidup secara benar, akurab, terbuka dan tepat waktu;

2. Menjaga keberlanjutan fungsi lingkungan hidup, dan;

3. Mentaati peraturan tentang baku mutu lingkungan hidup dan/atau kriteria baku kerusakan lingkungan hidup;

Fakta pengendalian perusahaan induk terhadap perusahaan anak yang menyebabkan anak perusahaan tidak dapat melaksanakan kewajiban untuk melakukan perlindungan dan pengelolaan lingkungan hidup, dalam keadaan ini induk perusahaan dapat dinyatakan sebagai "orang yang memberi perintah untuk melakukan tindak pidana" dan "orang yang bertindak sebagai pemimpin kegiatan tindak pidana “.

Perusahaan induk yang dinyatakan sebagai "orang yang memberi perintah untuk melakukan tindak pidana" dan "orang yang bertindak sebagai pemimpin kegiatan tindak pidana", pertanggungjawaban pidananya didasarkan Pasal 116 ayat (2) UUPPLH, oleh karena walaupun induk perusahaan dan anak perusahaan merupakan perusahaanperusahaan yang sebagai subyek hukum mandiri, namun perbuatan perusahaan- 
perusahaan yang sebagai subyek hukum mandiri, namun perbuatan yang dilakukan oleh anak perusahaan atas kebijakan dan atau instruksi induk perusahaan merupakan perusahaan-perusahaan yang sebagai subyek hukum mandiri, namun perbuatan yang dilakukan oleh anak perusahaan atas kebijakan dan atau instruksi induk perusahaan merupakan perbuatan yang dilakukan yang bertindak dalam lingkup kerja korporasi dalam hal ini perusahaan induk.Selanjutnya, meskipun perbuatan yang dilakukan tersebut dinyatakan sebagai dalam lingkup kerja perusahaan induk ( sebab perusahaan induk telah telah mengisntruksikan perbuatan tersebut kepada anak perusahaan), namun pelaku yang dapat dimintakan pertanggungjawaban pidana hanyalah pengurus dari induk perusahaan yakni mereka yang memberi perintah atau pemimpin dalam tindak pidana tersebut tanpa memperhatikan tindak pidana tersebut dilakukan secara sendiri atau bersama sama. Berkaitan dengan hal diatas perlu diperhatikan Peraturan Mahkamah Agung No 13 Tahun 2016 tentang Tata Cara Penanganan Perkara Tindak Pidana oleh Korporasi (PERMA No.13 Tahun 2016), Pasal 6 mengatur bahwa : "Dalam hal tindak pidana dilakukan oleh korporasi dengan melibatkan induk korporasi dan/atau korporasi subsidiari dan/atau Korporasi yang mempunyai hubungan dapat dipertanggungjawabkan pidana sesuai dengan peran masing-masing", seakan-akan perusahaan induk juga dapat dimintai pertanggungjawaban pidana, akan tetapi jika dicermati secara lebih lanjut rumuasan Pasal 116 ayat (2) UUPPLH, perusahaan tidak dapat dimintai pertanggungjawaban pidana, dan yang dapat dimintai pertanggungjawabaan pidana hanya pengurus saja.

\section{Penutup}

Berdasarkan pembahasan yang dilakukan mengenai membahas meminta pertanggungjawabanperusahaan induk atas perbuatan tindak pidana lingkungan hidup yang dilakukan oleh anak perusahaanmaka dapat ditarik kesimpulan :

Bahwa hubungan hukum yang terjadi antaraanak perusahaan dan induk perusahaan pada dasarnya di dasarkan adanya kewenangan melakukan pengendalian yang dimiliki oleh perusahaan induk. Hubungan hukum diantara perusahaan induk dan anak perusahaan menjadi hal sangat penting adalah berkaitan dengan penentuan siapa yang akan bertanggungjawab apabila terjadi tindak pidana lingkungan hidup.

Pertanggungjawaban pidana perusahaan induk terhadap perusahaan anak dalam hal terjadinya tindak pidana lingkungan dapat dilakukan dengan menerapkan doktrin tanggungjawab pengganti (vicarious liability) yang dianut Pasal 116 ayat (2) UUPPLH. Perusahaan induk dapat dimintakan pertanggungjawaban pidana atas tindakan lingkungan hidup yang dilakukan perusahaan anak dengan dasar bahwa tindak pidana tidak hanya dilakukan oleh perusahaan anak, tetapi perusahaan induk, yang mengendalikan perusahaan anak secara operating holding company, juga turut serta dalam terjadinya tindak pidana lingkungan tersebut. 
Volume 15, Nomor 1, Januari-Juni 2020

\section{Daftar Pustaka}

\section{Buku}

Alvi Syahrin, Ketentuan Pidana Dalam UU No.32 Tahun 2009 Tentang Perlindungan dan Pengelolaan Lingkungan Hidup, Jakarta: Sofmedia, 2011

Alvi Syahrin, Pertanggungjawaban Pidana Korporasi Dalam Ketentuan Pidana UndangUndang No.32 Tahun 2009 tentang Perlindungan dan Pengelolaan Lingkungan Hidup, Makalah, Disampaikan pada kegiatan "Simposiun Nasional, Pelatihan Hukum Pidana dan Kriminologie" Mahupiki, Padang, 3 April 2018

Boed Wahono, Pertanggungjawaban Pidana Korporasi, Jakarta: Kencana Prenada Media Group, 2010

Dwidja Priyatno, Kebijakan Legislasi Tentang Sistem Pertanggungjawaban Pidana Korporasi di Indonesia, Bandung: CV Utomo, 2003

Eddy.OS.Hiariey, Prinsip-Prinsip Hukum Pidana, Yogjakarta: Cahaya Atma Pustaka. 2014

Emmy Pangaribuan, Perusahaan Kelompok (Group Company/Concern), Seri Hukum Dagang, Yokjakarta: Fakultas Hukum Universitas Gajah Mada, 1994.

Herlina Manullang, Pertanggungjawaban Pidana Badan Usaha Commanditaire Venootschaap Dalam Tindak Pidana Lingkungan Hidup, Disertasi, Medan: USU, 2016

Jan Remmelink, Hukum Pidana;Komentar Atas Pasal-Pasal Terpenting Dalam Kitab Undang-Undang Hukum Pidana Belanda dan Padanaannya Dalam Kitab UndangUndang Hukum Pidana Indonesia, Jakarta: Gramedia Pustaka Utama, 2003

Kristian, Kejahatan Korporasi di Era Modern dan Sistem Pertanggungjawaban Pidana Korporasi, Bandung: Refika Aditama,, 2016

Muladi dan Dwidja Priyatna, Pertanggungjawaban Korporasi Dalam Hukum Pidana, Bandung: STHB, 1991

Mulyadi dan Dwidja Priyatno, Pertanggungjawaban Pidana Korporasi Dalam Hukum Pidana, Bandung: Sekolah Tinggi Hukum, 1991

Rufinus Hotmaulana Hutauruk, Penanggulangan Kejahatan Korporasi Melalui Pendekatan Restoratif Justice Suatu Terobosan Hukum, Jakarta: Sinar Grafika, 2013

Sukmareni, Pertanggungjawaban Pidana Korporasi Terhadap Tindak Korupsi Dalam SistemPeradilan Indonesia, dalam Revitalisasi Hukum Pidana Adat dan Kriminologie Kontemporer, Proceeding Call for Papers pada Simposium dan Pelatihan Hukum Pidana Ke V Diselenggarakan atas kerjasama Fakultas Hukum Universitas Andalas Padang dengan MAHUPIKI, Jokjakarta: Genta Publishing, 2018

Sulistiowati, Aspek Hukum dan Realitas Bisnis Perusahaan Group Di Indonesia, Cet Pertama, Jakarta: Erlangga, 2010 
Volume 15, Nomor 1, Januari-Juni 2020

\section{$\underline{\text { Makalah }}$}

Dwidja Priyatno, Pertanggungjawaban Pidana Korporasi, Makalah pada Simposiun Nasional Revitalisasi Hukum Pidana Adat dan Kriminologie Kontemporer Serta Pelatihan Hukum Pidana Dan Kriminologie Ke-V, Diselenggarakan Atas Kerjasama Bagian Hukum Pidana Fakultas Hukum Universitas Andalasa \& Masyarakat Hukum Pidana dan Kriminologie Indonesia (Mahupiki), Hotel Inna Muara, 2018

Nyoman Serikat Putra Jaya, Globalisasi HAM dan Penegakan Hukum, Makalah disampaikan pada matrikulasi Mahasiswa Progran Magister Ilmu Hukum UNDIP tahun 2010, pada tanggal 18 Sepetember 2010

Soedjono Dirdjosisworo, Hukum Pidana Indonesia dan Gelagat Kriminalitas Masyarakat Pasca Industri, Pidato Pengukuhan Jabatan Guru Besar, Bandung: Fakultas Hukum Universitas Panjajaran, 1991 